\title{
THE KING KONG CONTINGENT: SHOULD THE MEDICARE SECONDARY PAYER STATUTE REACH TO FUTURE MEDICAL EXPENSES IN PERSONAL INJURY SETTLEMENTS?
}

\author{
Norma S. Schmidt
}

When Medicare liens are involved in personal injury settlements, Medicare has been likened to an "800-pound gorilla" at the negotiations table. ${ }^{1}$ Any significant Medicare lien can dominate settlement negotiations because the Medicare Secondary Payer (MSP) statute grants Medicare a firstpriority right to prompt reimbursement for all pre-settlement conditional payments and wields the threat of double-damages for failing to fully consider Medicare's interests. ${ }^{2}$ If the Center for Medicare and Medicaid Services (CMS) continues the trend of extending the MSP statute's reach, Medicareeligible recipients of personal injury settlements risk losing much more of their settlement proceeds, not only to satisfy existing Medicare liens, but also to pay for future medical expenses that would otherwise be covered by Medicare. ${ }^{3}$ With such an expansion, the great "gorilla at the table" could start to take on the mythic proportions of Carl Denham's "Eighth Wonder of the World."

This note will first consider the legal boundaries of the MSP statute, and will then review arguments for and against adopting a new model similar to that in worker's compensation, which "sets aside" a portion of a settlement to cover future accident-related expenses for Medicare recipients. ${ }^{5}$ The conclusion reached herein is that the MSP statute should not be expanded due to fundamental differences in worker's compensation and personal injury

\footnotetext{
* J.D., University of Pittsburgh School of Law, 2007. Many thanks to Professor Lawrence Frolik for his guidance and support in writing this note, as well as to Professor Stella Smetanka, Judge David Torrey, and Attorneys John Campbell and Kemp Scales for their thoughtful feedback on prior drafts. Many thanks also to Attorneys Barbara Holmes and Robert Lewis for generously sharing their insights into this topic. All errors are, of course, my own.

1. John L. Tate \& Demetrius O. Holloway, Medicare Liens: A Stumbling Block to Settlement, 24 LJN's Prod. Liab. L. \& Strategy 8 (2005).

2. See infra notes $12-41$ and accompanying text.

3. See infra notes 60-61 and accompanying text.

4. KIng Kong (RKO Radio Pictures Cooper-Schoedsack 1933).

5. Matthew L. Garretson \& Jason L. Wolf, Settlements: Addressing Claims for Reimbursements and Preserving Benefits 20 (2005), available at http:/www.utahbar.org/cle/annualconvention/materials/ ho_settlements_2005.pdf.
} 
cases, as well as significant problems with the current worker's compensation model of Medicare Set Aside (MSA) arrangements. However, if such an expansion to the scope of the MSP statute is made, it should only occur after the serious problems with the current worker's compensation model have been resolved.

\section{Medicare and the Medicare Secondary Payer Statute}

Medicare is the federal health insurance program for individuals over the age of sixty-five and individuals under age sixty-five with permanent disabilities. ${ }^{6}$ Medicare provides healthcare benefits to nearly forty-three million Americans who have paid premiums for coverage, either directly, as in the doctor's insurance coverage of Medicare Part B or the prescription drug coverage of Medicare Part D, or by paying taxes while working, as in the hospital insurance of Medicare Part A.?

The MSP laws are "a collection of statutory provisions codified during the 1980 s with the intention of reducing federal health care costs." ${ }^{8}$ Before

6. 42 U.S.C. § 1395c (2000) (explaining Medicare Part A); 42 U.S.C. § 1395j (2000) (explaining Medicare Part B).

7. The Henry J. Kaiser Family Foundation, Medicare at a Glance 1 (2006), available at http://www.kff.org/medicare/upload/1066-09.pdf.

8. United States v. Baxter Int'l, Inc., 345 F.3d 866, 874 (11 th Cir. 2003). The language of the MSP statute (including the 2003 Amendments) reads in part:

(2) Medicare secondary payer

(A) In general

Payment under this subchapter may not be made, except as provided in subparagraph (B), with respect to any item or service to the extent that-

(i) payment has been made, or can reasonably be expected to be made, with respect to the item or service as required under paragraph (1), or

(ii) payment has been made or can reasonably be expected to be made under a workmen's compensation law or plan of the United States or a State or under an automobile or liability insurance policy or plan (including a self-insured plan) or under no fault insurance.

In this subsection, the term "primary plan" means a group health plan or large group health plan, to the extent that clause (i) applies, and a workmen's compensation law or plan, an automobile or liability insurance policy or plan (including a self-insured plan) or no fault insurance, to the extent that clause (ii) applies. An entity that engages in a business, trade, or profession shall be deemed to have a self-insured plan if it carries its own risk (whether by a failure to obtain insurance, or otherwise) in whole or in part.

(B) Conditional payment

(i) Authority to make conditional payment.

The Secretary may make payment under this title with respect to an item or service if a primary plan described in subparagraph (A)(ii) has not made or cannot reasonably be expected to make payment with respect to such item or service promptly (as determined in 
the advent of the MSP statute, Medicare would typically pay for healthcare for Medicare beneficiaries, even when another health insurance provider had a responsibility to pay. ${ }^{9}$ Under the MSP statute, Medicare does not pay for medical services when payment "has been made or can reasonably be expected to be made" by a primary plan, including workers' compensation, liability insurance plans, and self-insured plans. ${ }^{10}$ If such a primary plan does not pay promptly, Medicare may pay for healthcare with the condition that it later be reimbursed. Medicare can then take action to recoup its conditional payments from either the primary payer or any recipient of a primary plan's payment. $^{11}$

The MSP statute also grants Medicare a right of subrogation. ${ }^{12}$ Subrogation developed as an equitable doctrine preventing unjust enrichment "by substituting one person or entity in place of another in regard to some claim or right the second person or entity has against a third party." 13 This means that the insurer is,

"substituted" for the insured in regard to either all or some portion of the rights that the insured has to receive compensation from another source. An insurer asserting a subrogation right is usually viewed as "standing in the shoes" of the insured so that the insurer's rights are equal to, but no greater than, those of the insured. ${ }^{14}$

accordance with regulations). Any such payment by the Secretary shall be conditioned on reimbursement to the appropriate Trust Fund in accordance with the succeeding provisions of this subsection.

42 U.S.C. $\$ 1395 y(b)(2)(A)-(B)$ (2000 \& Supp. III 2003). For the legislative history of the MSP, see, e.g., H.R. REP. No. 96-1167, at 389 (1980), reprinted in 1980 U.S.C.C.A.N. 5526, 5752.

9. Walters v. Leavitt, 376 F. Supp. 2d 746, 750 (E.D. Mich. 2005).

10. 42 U.S.C. $\$ 1395 y($ b)(2)(A); Zinman v. Shalala, 67 F.3d 841, 843 (9th Cir. 1995) ("Responding to skyrocketing Medicare costs, Congress in 1980 enacted the Medicare Secondary Payer legislation ... requiring Medicare to serve as the secondary payer when a beneficiary has overlapping insurance coverage.").

11. 42 U.S.C. $\S 1395 \mathrm{y}(\mathrm{b})(2)(B) ;$ Baxter, 345 F.3d at 875 ("In a nutshell, the MSP declares that, under certain conditions, Medicare will be the secondary rather than primary payer for its insureds. Consequently, Medicare is empowered to recoup from the rightful primary payer (or from the recipient of such payment) if Medicare pays for a service that was, or should have been, covered by the primary insurer.”). See Robert T. Lewis \& Patty Meifert, Considering Medicare's Interest in Liability Cases, NAMSAP Newsletter (National Alliance of Medicare Set-Aside Professionals), April 2005, at 3.

12. 42 U.S.C. $\S 1395 \mathrm{y}(\mathrm{b})(2)(\mathrm{B})(\mathrm{iv})$ ("The United States shall be subrogated (to the extent of payment made under this subchaptertitle... for such an item or service) to any right under this subsection of an individual or any other entity to payment with respect to such item or service under a primary plan").

13. John Allan Appleman, 1-3 Appleman on Insurance Law and Practice $§ 3.1$ ( $2 \mathrm{~d}$ ed. 2002 ).

14. Id. 
Medicare's rights, however, are greater than a common law subrogation claim as Medicare's "right of recovery ... takes precedence over the claims of any other person or entity," 15 and reaches further than courts have generally permitted in the case of private health insurance. ${ }^{16}$ As explained by the Association of Trial Lawyers of America (ATLA):

in most states, it is the claims of an injured plaintiff that take priority over the subrogated claims of an entity that paid for the plaintiff's medical care. Under the "made whole" doctrine, a health insurer may not obtain reimbursement for medical payments from a third-party tortfeasor until the injured plaintiff has been fully compensated for his damages . . . (34 states have adopted the made whole doctrine by statute or court decision). ${ }^{17}$

\section{Medicare’s Rights as a Secondary Payer in Liability Settlements}

Despite the straightforward function of the MSP statute, "the statute is structurally complex - a complexity that has produced considerable confusion among courts attempting to construe it." ${ }^{\text {"18 }}$ CMS had mixed success in its early attempts to recover Medicare liens from liability awards or settlements because courts had different interpretations of, for instance, what constitutes a "self-insured" plan, ${ }^{19}$ and whether Medicare payments should be subject to reimbursement even if a primary payer could not be expected to pay promptly. ${ }^{20}$

15. Randal Kauffman, The War of the Cockatrice, 60 TEx. B.J. 310, 311 (1997).

16. As stated by the New Jersey Supreme Court in its analysis of health insurance subrogation rights: "[a]mong the courts that have addressed the question of the existence of a common-law equitable right of subrogation, the weight of authority concludes that no such right exists in the health insurance field." Perreira v. Rediger, 778 A.2d 429, 437 (N.J. 2001) (citations omitted). Some courts have even gone so far as to say that it would be unjust enrichment on the part of the insurer, should subrogation be permitted along with the retention of the premiums paid by the insured, resulting in a "double recovery." Johnny C. Parker, The Made Whole Doctrine: Unraveling the Enigma Wrapped in the Mystery of Insurance Subrogation, 70 Mo. L. Rev. 723, 737 (2005) (citations omitted).

17. Brief of the Ass'n of Trial Lawyers of Am. as Amicus Curiae in Support of Respondents, Ark. Dep't of Health \& Human Servs. v. Ahlborn, 2004 U.S. Briefs 1506, 8 (2006) (No. 04-1506) (citations omitted).

18. United States v. Baxter Int'l, Inc., 345 F.3d 866, 875 (11th Cir. 2003).

19. 42 U.S.C. $\$ 1395 y($ b)(2)(A)(ii). Compare Thompson v. Goetzmann, 337 F.3d 489, 498 (5th Cir. 2003), with Baxter, 345 F.3d at 898 ("We respectfully disagree with the Goetzmann dicta to the effect that there cannot be a self-insured plan absent a setting aside of the funds and formal procedures. However, especially because the statutory definition of a primary plan expressly includes self-insured plans, we see nothing in that context requiring either a set-aside of funds or formal procedures.").

20. See Baxter, 345 F.3d at 887. See also Courtney A. Rogers, Subrogation and Medicare: Eleventh Circuit Holding Facilitates Enforcement of Medicare Secondary Payor Statute-United States 
The MSP statute defines a "primary plan" as "a group health plan ... a workmen's compensation law or plan, an automobile or liability insurance policy or plan (including a self-insured plan) or no fault insurance." Some courts held that an uninsured defendant without a formal self-insurance plan did not meet the criteria for a primary plan from which Medicare could recover conditional payments. ${ }^{22}$ After a string of lower court decisions denied Medicare's attempts to recover conditional payments from personal injury awards, the Fifth Circuit, in Thompson v. Goetzmann, a suit against the manufacturer of a defective prosthesis, went so far as to threaten sanctions against the government for its continued pursuit of reimbursements from liability settlements involving alleged tortfeasors who have no formalized plan of self-insurance. ${ }^{23}$ Shortly after the Goetzmann decision, the Eleventh Circuit in United States v. Baxter, a class-action suit against the manufacturers of silicone breast-implants, disagreed with the reasoning of the Fifth Circuit regarding the meaning of "self-insured," stating that a formal "setting aside of the funds and formal procedures" is not a requirement. ${ }^{24}$ The Eleventh Circuit in Baxter also held that a primary insurer's prompt payment is not a prerequisite for Medicare reimbursement; however, it also cited a number of court decisions which came to the opposite conclusion due to multiple possible interpretations of the MSP statutory language..$^{25}$

In late 2003, Congress passed the Medicare Prescription Drug, Improvement, and Modernization Act (MMA) ${ }^{26}$ The Act, while best known for the new Medicare Prescription Drug Benefit, ${ }^{27}$ also contains little publicized changes, buried within the Act's 416 pages, which greatly strengthen the language of the MSP statute and resolve many of the

v. Baxter Int'l, Inc., 29 Aм. J. L. \& Med. 549, 550 (2003).

21. 42 U.S.C. $\S 1395 \mathrm{y}(\mathrm{b})(2)(\mathrm{A})$.

22. E.g., Goetzmann, 337 F.3d at 498 ("It is clear from the regulations implementing the MSP statute that the existence of a self-insurance plan requires that there by some form of arrangement - the creation ex ante of a fund and distribution procedures - for making potential payments to a set of prospective claimants."); Brown v. Am. Home Prods. Corp. (In re Diet Drugs Prods. Liab. Litig.), No. 99-20593, 2001 U.S. Dist. LEXIS 2959, at *37-38 (E.D. Pa. Mar. 21, 2001) (“The statute's requirement of the existence of a primary 'plan' connotes some type of formal arrangement by which an entity consciously undertakes to set aside funds to cover potential future liabilities and a formal procedure for processing claims made against that fund pursuant to the terms of the "plan."').

23. Goetzmann, 337 F.3d at 489, 503-04.

24. Baxter, 345 F.3d at 898 .

25. Id. at $888-89,892$.

26. Medicare Prescription Drug, Improvement, and Modernization Act of 2003 [hereinafter MMA], Pub. L. No. 108-173, § 301, 117 Stat. 2066 (2003).

27. MMA, § 301, 117 Stat. at 2071. 
discrepancies in interpretation by the courts. ${ }^{28}$ With the sting of the Goetzmann decision still fresh, Congress elaborated the definition of "selfinsured" to include, for instance, corporations that simply carry the risk of not purchasing insurance. ${ }^{29}$ The "prompt payment" language from section(A)(ii) was deleted from the statute, making it clear that even if a primary payer cannot be reasonably expected to pay in the near future, Medicare nevertheless has a right to reimbursement. ${ }^{30}$ These two significant changes to the MSP statute are considered "technical" and "clarifying," respectively, and are effective retroactively from the date of the original statutory enactments. ${ }^{31}$

The MSP statute, especially after the 2003 MMA "clarifications," makes Medicare a dominating force in settlement negotiations. Medicare's recovery of conditional medical payments takes precedence over any other claim against settlement proceeds, including those of Medicaid, and trumps even the injured party's right to reimbursement. ${ }^{32}$ Medicare's extensive right to recovery has thus been described as a "super lien." ${ }^{33}$ The MSP statute gives CMS a cause of action in any situation in which a primary plan responsible for payment of an item or service fails to make the appropriate payment to Medicare. ${ }^{34}$

Everyone participating in a settlement involving Medicare liens should be aware of the scope of the MSP statute, as it grants CMS the right to recoup its conditional payments from a "beneficiary, provider, supplier, physician, attorney, State agency or private insurer that has received a third party payment. ${ }^{, 35}$ If Medicare is not reimbursed and CMS takes legal action, the MSP statute grants CMS the right to collect double damages plus interest for any attempt at cost shifting from a primary payer onto Medicare. ${ }^{36}$

\footnotetext{
28. For a discussion of the primary effects of the MMA on the MSP statute, see Brown v. Thompson, 374 F.3d 253, 257-58 (4th Cir. 2004).

29. 42 U.S.C. $\S 1395$ y(b)(2)(A); MMA, § 301, 117 Stat. at 2222. See Roger J. Larue \& Daniel Q. Posin, Medicaid, ERISA, and Other Medical Liens Against Personal Injury Recoveries: Plus Congress' 2003 Christmas Gift to Medicare, 51 LA B.J. 334, 335 (2004).

30. 42 U.S.C. $\S 1395 y(b)(2)(A)(i i) ; M M A, \S 301,117$ Stat. at 2221. See Brown v. Thompson, 374 F.3d at 258

31. MMA, § 301,117 Stat. at $2221-22$.

32. 42 C.F.R. $\S 411.24(c)$ (2005). See Tate \& Holloway, supra note 1.

33. Larue \& Posin, supra note 29; Lewis \& Meifert, supra note 11.

34. 42 C.F.R. $\S 411.24(b)(2005)$

35. Id. $\S 411.24(\mathrm{~g})$.

36. 42 U.S.C. $\S 1395 y($ b)(2)(B)(iii); 42 C.F.R. $\S 411.24(c)(2)$. For a discussion of the interest calculations on the MSP debts, see Matthew L. Garretson \& Jason Wolf, Settlements: Addressing Claims for Reimbursements and Preserving Benefits 12 (2005), available at http://www.utahbar.org/cle/ annualconvention/materials/ho_settlements_2005.pdf (last visited Nov. 2, 2006).
} 
CMS is permitted to recover the full amount of a Medicare lien even if the amount of the lien exceeds the amount a plaintiff receives. ${ }^{37}$ This right to full recovery applies also to settlement agreements lacking a determination or admission of liability. ${ }^{38}$ CMS may seek reimbursement of Medicare liens from the entire settlement amount (less attorneys' fees) because the MSP regulations do not require Medicare to adjust its lien amount according to the intended allocation of a settlement award. ${ }^{39}$ For instance, in situations where parties have agreed that a pre-existing condition accounts for a portion of the medical expenses, Medicare will not necessarily reduce the amount it seeks to recover accordingly. ${ }^{40}$ Thus " $[\mathrm{t}]$ he practitioner who negotiates settlements with an insurance carrier . . . should not rely on Medicare to pick up any unreimbursed medical expenses or to assume a proportionate share of the total damages." ${ }^{41}$

While protecting the fiscal integrity of the Medicare program by making the program a secondary payer makes sense from a financial standpoint, the broad scope of the MSP statute and CMS's increased enforcement efforts have serious consequences for settling personal injury cases. The existence of potentially huge medical liens makes it more difficult to reach an agreement in the first place, as the settlement amount must fully account for conditional Medicare payments, over and above the additional needs of the plaintiff, leading to larger settlement amounts. ${ }^{42}$ Parties are often forced to settle without even knowing the exact amount of an outstanding Medicare lien. As explained by ATLA:

37. 42 C.F.R. $\S 411.24(\mathrm{c})$; Garretson \& Wolf, supra note 36, at 12.

38. 42 U.S.C. $\$ 1395 y($ b)(2)(B)(ii)-(iii). See Garretson \& Wolf, supra note 36, at 10.

39. 42 C.F.R. § 411.24(c); Zinman v. Shalala, 67 F.3d 841, 843 (9th Cir. 1995) ("HHS has interpreted the MSP legislation to allow full recovery of conditional Medicare payments even when the beneficiary's settlement is for less than her total damages (i.e., a discounted settlement)."). See also Garretson \& Wolf, supra note 36, at 10 (Only with a court order on the merits of the case will Medicare hold exempt from its MSP claim those portions of the award allocated to pain and suffering, etc.). In the case of Medicaid liens, the Supreme Court recently held that the state Medicaid agency was limited in its right to reimbursement to the portion of a personal injury settlement designated for medical care. Ark. Dep't of Health \& Human Servs. v. Ahlborn, 126 S. Ct. 1752 (2006). While Ahlborn specifically involves a Medicaid lien, many of the same issues also apply to Medicare liens. Brief of the Ass'n of Trial Lawyers of Am. as Amicus Curiae in Support of Respondents, supra note 17, at 2.

40. Garretson \& Wolf, supra note 36, at 11. See also Matthew L. Garretson, A Practical Approach to Proactive Client-counseling and Avoiding Conflicts of Interest in Aggregate Settlements, 6 LOY. J. PuB. INT. L. 19, 36 (Fall 2004). (2005).

41. 1-9 John J. Regan et al., Tax, Estate \& Financial Planning for the Elderly § 9.19(4)

42. See Tate \& Holloway, supra note 1. 
The federal Medicare program and its contractors are notorious for refusing to provide information regarding claimed lien amounts until after a tort claim has been settled. ... Under these circumstances, plaintiffs are forced to bear not only the uncertainty of litigation, but also substantial uncertainty about the amount of any recovery that may be claimed by the government for reimbursement of medical costs. ${ }^{43}$

The potential harshness of the MSP statute is softened somewhat by the opportunity to seek a hardship waiver from CMS, which may be granted based on difficulty of a recovery recipient to meet daily living expenses such as food, clothing, and rent. ${ }^{44}$ Nevertheless, the MSP statute gives CMS tremendous power when Medicare liens are involved in personal injury settlements.

\section{Medicare's Additional Rights as a Secondary Payer for Future Medical Expenses in Workers' Compensation Settlements}

Medicare has a long history as a secondary payer in workers' compensation cases. The MSP statute originated in laws from the 1960s, which required reimbursement of Medicare payments made to an individual eligible for workers' compensation benefits. ${ }^{45}$ The MSP laws require reimbursement for payments made prior to a workers' compensation award or settlement. Moreover, the laws make Medicare a secondary payer for accident-related future medical expenses when there has been a "commutation" of future medical expenses in the settlement agreement, or in the case of disputed liability, a "compromise" settlement in which payments for future medical expenses have been foreclosed. ${ }^{46}$ The MSP regulations

43. Brief of the Ass'n of Trial Lawyers of Am. as Amicus Curiae in Support of Respondents, supra note 17 , at 11 .

44. 42 C.F.R. $\S 411.28$ (2005); Tate \& Holloway, supra note 1:

The regulations and internal manuals interpreting the MSP statute allow for the waiver of repayment of benefits when repayment defeats the purposes of the statute. The benefits recipient must request a waiver from the CMS, with the government's waiver decision based largely on the recipient's ability to meet ordinary and nec essary living expenses. These expenses include food, clothing, rent, maintenance, insurance, and expenses for the support for others for whom the beneficiary is legally responsible.

45. United States v. Baxter Int'l, Inc., 345 F.3d 866, 875 (11th Cir. 2003).

46. 42 C.F.R. $\S 411.46$ (d) (2005). Medicare distinguishes between a "commutation" of future medical expenses, which are "intended to compensate the individual for all future medical expenses required because of the work-related injury or disease," 42 C.F.R. $\S 411.46(a)$, in which case Medicare will not pay for future medical expenses until such amount has been expended, 42 C.F.R. $\S 411.46(a)$, and a "compromise" in which liability may be disputed, 42 C.F.R. $\S 411.46(\mathrm{~b})(1)$. The regulations provide that unless the compromise settlement "appears to represent an attempt to shift to Medicare the responsibility for payment of medical expenses for the treatment of a work-related condition," 42 C.F.R. § 411.46(b)(2), 
give CMS the authority to disregard a settlement allocation if cost-shifting onto Medicare for future medical expenses is apparent. This provision permits Medicare to deny coverage of that condition in the future. ${ }^{47}$ As explained in a CMS memorandum:

Medicare cannot accept the terms of the settlement as to an allocation of funds of any type if the settlement does not adequately address Medicare's interests. If Medicare's interests are not reasonably considered, Medicare will refuse to pay for services related to the [Worker's Compensation] injury (and otherwise reimbursable by Medicare) until such expenses have exhausted the amount of the entire [Worker's Compensation] settlement. $^{48}$

Consider a hypothetical example in which the parties to a workers' compensation case settle for $\$ 75,000$ with both parties agreeing that $\$ 50,000$ adequately represents loss of income and $\$ 25,000$ adequately represents future medical expenses. If CMS believes the $\$ 25,000$ is too low of an amount for future medical expenses and is an attempt to shift costs onto Medicare, the regulations allow Medicare to refuse to pay for any accident-related medical expense until the entire $\$ 75,000$ has been spent on the cost of such care. ${ }^{49}$

While these regulations have been in effect for many years, Medicare has only relatively recently begun to aggressively assert secondary payer status for future medical expenses. ${ }^{50}$ CMS issued a Memorandum in 2001 addressing the commutation of future benefits in worker's compensation cases and explaining the use of Medicare Set-Aside (MSA) arrangements to prevent Medicare from making mistaken payments for medical expenses related to the work injury when a primary payer has already made a payment intended to cover future medical expenses. ${ }^{51}$ With an MSA arrangement, a portion of the

Medicare will pay for future accident-related medical expenses when a lump-sum compromise settlement forecloses the possibility of future payment of workers' compensation benefits, 42 C.F.R. $\S 411.46(\mathrm{~d})(1)$, unless the settlement specifically allocates a portion of the settlement as compensation for future medical expenses, 42 C.F.R. $\S 411.46(d)(2)$. There seems to be some inconsistent use of the terms "commutation' and "compromise" by CMS. For a more thorough discussion of this issue, see Edward M. Welch, Medicare and Worker's Compensation After the 2003 Amendments 10-11 (2004), available at http://www.lir.msu.edu/wcc/Medicare/Medicare\%20Web\%2004.pdf (last visited Nov. 2, 2006).

47. 42 C.F.R $\$ 411.46(\mathrm{~b})(2)$; Rafael Gonzalez, Reasonable Consideration of Medicare's Interests in Workers' Compensation Settlements, 77 FlA. B.J. at 81-82 (Nov. 2003).

48. Memorandum from Thomas L. Grissom, Dir., Ctr. for Medicare Mgmt. to All Reg'l Adm'r (Apr. 22, 2003), available at http://www.cms.hhs.gov/WorkersCompAgencyServices/Downloads/ 42203Memo.rtf.

49. $I d$.

50. David B. Torrey et al. \& Andrew E. Greenberg, Workers' Compensation: Law and Practice $§ 15: 116$ (2002 \& Supp. 2005).

51. Memorandum from Parashar B. Patel, Deputy Dir., Purchasing Policy Group, Ctr. for Medicare 
settlement is "set aside" and applied specifically to future medical expenses which would otherwise be covered by Medicare. ${ }^{52}$ Only after this amount has been spent will Medicare begin to pay for medical care related to the accident. $^{53}$ For cases meeting certain criteria, CMS will provide presettlement approval of the MSA amount. ${ }^{54}$

MSA arrangements have become "standard practice" for addressing Medicare's interests in workers' compensation settlements, even though there appears to be no case law requiring MSAs. ${ }^{55}$ Medicare's pre-approval of a workers' compensation settlement eliminates the risk of a future denial of Medicare benefits, and assures the parties that Medicare's interests have been reasonably considered.

\section{Must Medicare's Interest be “Reasonably Considered” Regarding Future Medical Expenses in Personal Injury Settlements?}

The MSP statute broadly states that Medicare will not pay for "any item or service to the extent that ... payment has been made or can reasonably be expected to be made under a workmen's compensation law or plan . . . or liability insurance policy or plan. .." for an item or service otherwise covered by Medicare. ${ }^{56}$ When a personal injury settlement makes a specific allocation for future medical expenses, CMS may be able to argue that such a payment "has been made," and that Medicare should be a secondary payer to that portion of the settlement. ${ }^{57}$ However, the regulations dealing with Medicare

Mgmt. to All Assoc. Reg'l Adm'r (July 23, 2001) [hereinafter Patel Memo], available at http://new.cms.hhs.gov/WorkersCompAgencyServices/Downloads/72301Memo.rtf. See Lewis \& Meifert, supra note 11 , at 4 .

52. Centers for Medicare and Medicaid Services, Workers Compensation Medicare Set-aside Arrangements [hereinafter CMS, WCMSAs], at http://new.cms.hhs.gov/WorkersCompAgency Services/04_wcsetaside.asp (last visited Nov. 2, 2006).

53. $I d$.

54. CMS, WCMSAs, supra note 52:

A WCMSA may be submitted to CMS for review in the following situations:

The claimant is currently a Medicare beneficiary and the total settlement amount is greater than $\$ 25,000 ;$ OR

The claimant has a "reasonable expectation" of Medicare enrollment within 30 months of the settlement date and the anticipated total settlement amount for future medical expenses and disability/lost wages over the life or duration of the settlement agreement is expected to be greater than $\$ \mathbf{2 5 0 , 0 0 0}$.

55. Lewis \& Meifert, supra note 11.

56. 42 U.S.C. $\S 1395$ y(b)(2)(A) (2000 \& Supp. 2003).

57. John J. Campbell, Medicare Set Aside Arrangements for Future Medical Expenses in Third Party Liability Settlements, The Medicare Set Aside Bulletin, Feb. 14, 2005, at http://www.jjcelderlaw 
as a secondary payer to post-settlement medical expenses are specific to worker's compensation, ${ }^{58}$ weakening the argument that the MSP statute applies to future medical expenses in personal injury cases. Even if the MSP statute arguably applies to a specific allocation of future medical expenses in personal injury cases, Medicare's authority to disregard a settlement allocation that appears to shift costs onto Medicare refers only to the treatment of a "work-related condition." 59

Despite these legal limitations, CMS is beginning to assert secondary payer status for future medical expenses in any personal injury settlement in which future medical costs are a "consideration," even if there is no allocation for future medical expenses in the settlement agreement. ${ }^{60} \mathrm{CMS}$ is working on an official statement regarding future medical expenses in third-party liability settlements, but in the meantime it requires the parties to "reasonably consider Medicare's interests." ${ }^{61}$ But what does "reasonably consider" mean? Is this based on a "good faith" standard? ${ }^{62}$ If future medical expenses are not adequately designated or properly expended, who will be held responsible? ${ }^{63}$

.com/CMS\%20TPL\%20News.htm.

58. 42 C.F.R. $\S 411.46$ (2005) (The regulation stating that Medicare will not pay for post-settlement medical expenses until the amount allocated in the settlement for future medical expenses has been spent is found under the subsection "Limitations on Medicare Payment for Services Covered Under Workers' Compensation."). See Campbell, supra note 57.

59. 42 C.F.R. $\S 411.46(\mathrm{~b})(2)$.

60. Lewis \& Meifert, supra note 11, at 4:

CMS has advised that it is not asking for Medicare Set-Aside arrangements, nor does it have any current plans for a formal process for reviewing and approving Medicare Set-Aside arrangements, in liability cases.

However, even though no formal process exists, there is an obligation to inform CMS when past or future medicals were a consideration in reaching the liability settlement, judgment, or award whether or not specifically provided for in the settlement, judgment, or award in cases involving a Medicare beneficiary.

In addition, CMS expects that any settlement funds that were intended to compensate for future medicals be spent for that purpose before any claims related to the settlement, judgment or award are submitted to Medicare for payment.

61. John J. Campbell, Update on Medicare's Position Regarding Future Medical Expenses in Third Party Liability Settlements, The Medicare Set Aside Bulletin, Feb. 21, 2005, at http://www.jjcelderlaw.com/CMS\%20TPL\%20News\%20Update.htm (“CMS currently has no official procedure for review of Medicare Set Aside Arrangements (MSAs) in TPL settlements ... . However, CMS does require that the parties "reasonably consider Medicare's interests" in TPL settlements.").

62. Garretson \& Wolf, supra note 5, at 20 ("While there is not yet published standards to utilize in calculating set asides in liability settlements, the general standard for 'set aside' calculation is a 'Good Faith' standard.").

63. See Lewis \& Meifert, supra note 11, at 4. 
What kind of documentation is required by CMS $?^{64}$ Such important questions have not been answered.

In a situation where Congress has not directly addressed the issue in the statutory language, an agency's interpretation will be upheld if it is based on a "permissible construction of the statute." ${ }^{65}$ However, a "court need not defer to statutory interpretation that is "nothing more than the litigation position of agency counsel that is wholly unsupported by regulations, rulings, or administrative practice." "'66 The language of the MSP statute and regulations does not seem to support a deference to CMS's position that Medicare is a secondary payer for post-settlement medical expenses outside of workers' compensation cases, except perhaps to the extent that a specific allocation has been made for future medical expenses in the settlement agreement. ${ }^{67}$

When the regulations and policy statements are unclear, and when the other party's interpretation is reasonable, a court may hold that there has been no notice of the agency's interpretation of the law, and a party not abiding by the agency's position may not be held liable. ${ }^{68}$ Because CMS has not issued any clear guidance as to what parties in personal injury settlements are expected to do regarding future medical expenses, and because the regulations are silent as to any authority to claim secondary payer status for future medical expenses except in workers' compensation cases, CMS' position that parties must "reasonably consider" Medicare's interest regarding future medical expenses in personal injury cases may be unenforceable not only due to a lack of legal authority, but also due to a lack of notice.

While CMS' position that Medicare's interests be "reasonably considered" in personal injury settlements involving future medical expenses may be in line with the trend towards expanding the reach of the MSP statute, ${ }^{69}$ this position does not appear to be a legal requirement. As one workers' compensation scholar put it, “[w] hy shouldn't Medicare be treated

64. Id

65. Chevron, U.S.A., Inc. v. Natural Res. Def. Council, Inc., 467 U.S. 837, 842-43 (1984).

66. Mason v. Am. Tobacco Co., 346 F.3d 36, 43 (2d Cir. 2003).

67. See supra notes 56-59 and accompanying text.

68. Gen. Elec. Co. v. United States EPA, 53 F.3d. 1324, 1333-34 (D.C. Cir. 1995) (“"[w]here ... the regulations and other policy statements are unclear, where [GE's] interpretation is reasonable, and where the agency itself struggles to provide a definitive reading of the regulatory requirements, a regulated party is not 'on notice' of the agency's ultimate interpretation of the regulations, and may not be punished.").

69. Expansions of the MSP are discussed in Baxter, 345 F.3d at 877 ("Since enacting the MSP statute, Congress has expanded its reach several times, making Medicare secondary payer to a greater array preprimary coverage sources, and creating a larger spectrum of beneficiaries who no longer may look to Medicare as their primary source of coverage."). 
as an adversary? Adversaries have certain rights, they must be given notice and an opportunity to protect their interest but why should other parties be expected to protect their interest, especially since Congress has not seen fit to require this in the law?"70

\section{Should the MSP Statute be Expanded to Cover Future Medical Expenses in Personal Injury Cases?}

The fundamental differences between workers' compensation and personal injury make the application of the MSP statute toward future medical expenses in personal injury cases more unwieldy than in worker's compensation. As explained by the court in Zinman v. Shalala, an analogy between workers' compensation and liability damages is inappropriate because workers' compensation awards are based on precise calculations of future wages and medical expenses. ${ }^{71}$ Personal injury awards, on the other hand, consider non-economic damages such as pain and suffering and loss of enjoyment of life, as well as non-compensatory punitive damages. ${ }^{72}$ Although future medical expenses are often a factor in personal injury settlements, the wide range of other possible considerations makes the apportionment of damages much more complicated than in workers' compensation cases. ${ }^{73}$

Causation may also be more difficult to prove in personal injury cases. For instance, in medical malpractice, the plaintiff was usually already suffering from an illness or injury when the alleged negligence occurred, making it hard to distinguish the harm caused by negligence from the results of the underlying condition. ${ }^{74}$ The difficulty of precisely apportioning damages in personal injury cases would make it harder for CMS to determine if there has been an attempt to shift costs of future medical expenses onto Medicare.

While the greater difficulty in precisely apportioning damages in personal injury settlements is an argument for not expanding the MSP statute to future medical expenses in liability cases, the Ninth Circuit's logic in Zinman v. Shalala was to allow Medicare to claim up to the entire settlement amount in reimbursement for conditional payments made, so as not to "require a

70. Welch, supra note 46, at 23.

71. 67 F.3d 841, 846 (9th Cir. 1995).

72. 3 David W. Louisell \& Harold Williams, 3-18 Medical Malpractice $§ 18.01$ (2) (2006).

73. Id. at. $\S 10.02$ (Indicating that future medical expenses are just one type of damages among many being considered.).

74. Id. at. $\S 10.01$. 
factfinding process to determine actual damages or ... place Medicare at the mercy of a victim's or personal injury attorney's estimate of damages.",75 Applying this same reasoning to future medical expenses is problematic due to uncertainty of future healthcare costs. ${ }^{76}$ Specially trained healthcare professionals may make an estimate of future medical needs, but these can never be more than educated guesses, and Medicare will not necessarily accept a doctor's estimate of future healthcare expenses. ${ }^{77}$

Given the long delays and uncertainty which currently exist regarding Medicare liens in personal injury settlements, there is reason to be concerned that requiring CMS to not only verify an existing lien amount, but also preapprove an MSA proposal could lead to additional delays in the settlement process. Instances of workers' compensation settlement negotiations falling apart as parties wait a year or more for CMS approval of an MSA amount have occurred. ${ }^{78}$ To remedy the situation, CMS has taken steps to make the MSA approval process more efficient, although delays may still occur. ${ }^{79}$

Settlement delay and uncertainty are just two of the many problems with the current model for protecting Medicare's interests as a secondary payer of post-settlement medical expenses in workers' compensation cases. ${ }^{80}$ A proposed set of fourteen changes to the current workers' compensation model

75. 67 F.3d 841, 846 (9th Cir. 1995). However, ATLA has suggested that an equitable apportionment of a settlement be done by the courts. See infra notes 105-06 and accompanying text.

76. Some states have specifically addressed the issue of subrogation regarding future medical expenses. In revising its collateral source rule, Pennsylvania declined to adopt a "future" collateral source rule because "the legislature was sensitive to the fact that the existence of such coverage at the time the plaintiff is injured is no guarantee that similar benefits will be available in the future." Gerald A. McHugh Jr., Legislation Brings Sweeping Changes to Pennsylvania Tort Law: An Interpretative Analysis of Medical Malpractice Reform, 25 PA. L. WEEKLY 12 (2002).

77. CMS states that "Medicare will consider accepting a life care plan or similar evaluation from a non-treating physician. . . . Please note that such a life care plan or evaluation is not automatically conclusive." Memorandum from Thomas L. Grissom, supra note 48, at 6.

78. See Eric J. Oxfeld, National Issues Affecting Impacting Workers' Compensation, at http://www.riskinstitute.org/FP_DOCS/NationalIssuesWC-PERISymposiumPaper.pdf (from http://www.riskinstitute.org, follow "Symposium Center" hyperlink; then follow "Symposium Papers" hyperlink; then follow "Workers' Compensation: Containing Costs and Managing Outcomes" hyperlink) (last visited Nov. 2, 2006) (paper presented Dec. 11, 2003 at the Workers' Compensation: Containing Costs and Managing Outcomes Symposium of the Public Entity Risk Institute) at 4. at S-9.

79. Eric J. Oxfeld, Congress Must Reform Medicare Set Asides, Fla. Underwriter, May 2006,

80. See Press Release, New Jersey State Bar Association, NJSBA Seeks Remedy to Workers' Comp Backlog, New Jersey State Bar Association (Feb. 14, 2005), available at http://www.njsba.com/ press/press_title_link.cfm?pressid=413 (listing the 14 points contained in ABA Resolution No. 109B). 
was adopted in February 2005 by the American Bar Association. ${ }^{81}$ The list includes:

- Setting a deadline for approval of a settlement, "after which time approval should be deemed to occur by law." 82

- Establishing an appeals procedure to dispute a CMS ruling, if necessary. ${ }^{83}$

- Allowing the cost of protecting Medicare's interests in the settlement process and the cost of administration of a set-aside trust to be funded out of the money allocated for Medicare. $^{84}$

Most of the concerns that underlie these proposals would also apply to personal injury cases. Consider, for instance, the lack of an appeals process for a CMS denial of a workers' compensation settlement allocation and proposed MSA amount. ${ }^{85}$ If CMS rejects a MSA proposal, the injured person risks a denial of future Medicare benefits. ${ }^{86}$ With the plaintiff having an incentive to make the set-aside amount as low as possible, and CMS having the incentive to make the set-aside amount as high as possible, clearly an adversarial situation exists, but with CMS having the ultimate power of approval or denial. "Generally, the law guarantees an appeal from every final decision of an administrative agency. [However,] CMS apparently takes the position that this is not a final determination." ${ }^{17}$ Currently, any appeal can only be made after a denial of specific Medicare benefits through the ordinary administrative appeals process. ${ }^{88}$ This process could take years, and clearly is not a satisfactory solution for parties needing a timely closure to a settlement agreement.

In determining whether or not to approve a MSA proposal, CMS takes the approach in workers' compensation that it is not simply the apportionment of the settlement being approved, but also whether the settlement amount is

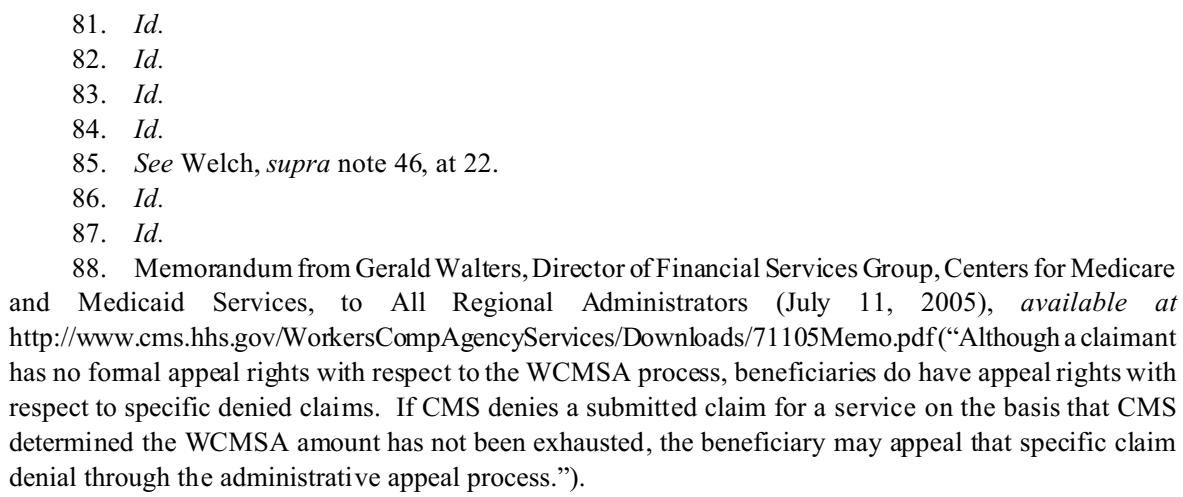

88. Memorandum from Gerald Walters, Director of Financial Services Group, Centers for Medicare and Medicaid Services, to All Regional Administrators (July 11, 2005), available at http://www.cms.hhs.gov/WorkersCompAgencyServices/Downloads/71105Memo.pdf(“Although a claimant has no formal appeal rights with respect to the WCMSA process, beneficiaries do have appeal rights with respect to specific denied claims. If CMS denies a submitted claim for a service on the basis that CMS determined the WCMSA amount has not been exhausted, the beneficiary may appeal that specific claim denial through the administrative appeal process."). 
sufficient to adequately cover the plaintiff's future accident-related medical expenses. ${ }^{89}$ This approach has raised concern among some scholars that " $[t]$ he federal government is now ex ercising scrutiny over state worker compensation systems," with CMS agents put in a position of "second guessing experienced workers' compensation people concerning liability under state workers' compensation laws." ${ }^{90}$ Similar concerns regarding the role of the federal government in state law matters could also apply to personal injury cases.

An effect of the growing scope of the MSP statute is a disincentive to settle when the amount recovered would primarily be paid to satisfy government liens (and attorney fees), thus undermining the public interest of efficient resolution of disputes through settlement. ${ }^{91}$ As explained by ATLA in an amicus brief to the Supreme Court in Arkansas Department of Health and Human Services v. Ahlborn:

an injured plaintiff who had received medical treatment funded by Medicaid would have little incentive to settle her personal injury lawsuit for an amount that fell far short of her total claim for damages, because any settlement award immediately would be reduced by the total amount claimed by the state Medicaid agency for reimbursement of medical expenses paid. In addition, the plaintiff would be obliged to pay her attorneys' fees and costs. Only the remainder would belong to the injured plaintiff. Where the cost of treatment funded by Medicaid was substantial, there would be relatively little, if any, money left to compensate plaintiff for her injuries.

Under this scenario, all of the costs and risks of litigation, and all of the uncertainty about potential recovery, would be borne by the plaintiff. The state Medicaid agency would bear none of this risk, and none of these costs, while obtaining a full recovery. ${ }^{92}$

While Ahlborn deals specifically with the state Medicaid liens, many of ATLA's arguments also apply to Medicare liens under the MSP statute. ${ }^{93}$ A disincentive to settle will result in more plaintiffs "taking their chances" at trial. If the plaintiff loses at trial then Medicare recovers nothing. ${ }^{94}$ This result undermines the whole purpose of the MSP statute, which is to have a primary payer take financial responsibility for a Medicare recipient's healthcare and to leave Medicare as a payer of last resort. ${ }^{95}$ The problem

89. See Welch, supra note 46 , at 8.

90. Id. But see id. at 9-10 (explaining how CMS memorandum and regulations leave much unanswered regarding the degree of deference owed to a state workers' compensation agency's approval of a settlement allocation).

91. Brief of the Ass'n of Trial Lawyers of Am. as Amicus Curiae in Support of Respondents, supra note 17 , at $9-10$.

92. Id. at $10-11$.

93. Id. at 2 .

94. Id. at 13 .

95. See Larue \& Posin, supra note 29. 
would only be compounded if the MSP statute were applied to future as well as past medical expenses in personal injury cases. Medicare set aside amounts must now also account for future prescription drug needs, ${ }^{96}$ which can potentially add hundreds of thousands of dollars to the set aside, making the disincentive to settle that much greater. ${ }^{97}$

If the current model in workers' compensation of MSA arrangements is expanded to cover personal injury cases, the following situation could arise: Plaintiff receives a personal injury settlement. The bulk of this amount must be paid to government healthcare liens for past medical expenses and attorney fees, with the remainder used to fund a MSA account. Once the MSA amount has been approved, plaintiff is then burdened with administering the MSA account. ${ }^{98}$ In workers' compensation, at least for professionally administered MSAs, the administrative process entails sending annual reports to the regional Medicare office which "must indicate all of the expenditures from and deposits made into the fund" for that period of time. ${ }^{99}$ The administrator of the MSA account must ensure that billing for medical services is handled properly, taking care that only those services which would otherwise be covered by Medicare are paid for with MSA account funds. ${ }^{100}$ After the funds have been exhausted, "the custodian must then forward a report to the appropriate Medicare regional office detailing all expenses paid from the fund and all deposits for the life of the fund." 101 The effective management of such an account requires competency in healthcare claims administration, a clear understanding of what services Medicare covers, and meticulous record

96. Memorandum from Gerald Walters, Director, Financial Services Group, to All Regional Administrators (Dec. 30, 2005), available at http://www.cms.hhs.gov/WorkersCompAgencyServices/ Downloads/123005Memo.pdf.

97. Nancy Grover, Set-Asides Go Skyward: Medicare's Drug Benefit Creates Sticker Shock in WC Settlements, RisK \& INS., Apr. 15, 2006, at 10.

98. Centers for Medicare and Medicaid Services, Administering WCMSAs, at http://new.cms.hhs.gov/WorkersCompAgencyServices/07_administeringwcmsas.asp (last visited Nov. 2, 2006):

Administrative fees/expenses for administration of the WCMSA and/or attorney costs specifically associated with establishing the WCMSA cannot be charged to the set-aside arrangement. The CMS will no longer be evaluating the reasonableness of any of these costs because the payment of these costs must come from some other payment source that is completely separate from the WCMSA funds.

99. Melisa C. George \& Bennett L. Pugh, Dealing with Medicare Issues in Workers ' Compensation Settlements, 77 Fla. B.J. 47, 49 (Feb. 2003), reprinted in Elder Law: CASEs and Materials 269, 270 (Lawrence A. Frolik, Alison McChrystal Barnes eds., 3d ed., 2003). See also Patel Memo, supra note 51, at 7 .

100. Gonzalez, supra note 47 , at $84-85$.

101. Id. 
keeping. Such detailed administration requirements will be burdensome, if not impossible, for most settlement recipients to handle. Although a professional may be hired to manage the account, under the current workers' compensation model, such professional fees may not be paid for out of the MSA account, resulting in significant additional expense. ${ }^{102}$ Due to the extensive requirements of administering the MSA, mistakes are likely to occur and it may be difficult to prove that all the funds were spent according to CMS's precise standards, raising the risk of contested Medicare eligibility later. The burden of the MSA administration makes allowing the continuation of payments by Medicare without interruption more attractive than bringing suit. The latter alternative not only risks losing much of the settlement to satisfy government healthcare liens, but also adds the burden of administering an MSA account for future medical expenses.

Because of these difficulties, some scholars suggest that Medicare administer the MSA accounts. ${ }^{103}$ This approach would relieve the individual of the burden of self-administering the MSA, or the expense of hiring a professional MSA administrator, and would ensure a smooth transition for the settlement recipient back into Medicare-funded coverage once the MSA funds have been depleted. Other experts, however, have expressed concern that having CMS administer MSA accounts would create an overly expensive administrative burden for CMS and present difficult issues regarding the appropriate fiduciary standards for administering such accounts. ${ }^{104}$

Regarding the proper allocation of settlement damages, ATLA presents a proposal in its amicus brief in Ahlborn to adopt a rule of "equitable apportionment" of a tort settlement among the various claimants in order to "promote the efficient resolution of judicial disputes, likely increase state Medicaid agency's third-party liability reimbursements, and be equitable to all claimants, including the state and federal governments." 105 Such hearings are not unusual, as they are often used to apportion settlements into taxable and non-taxable categories and are common practice in a number of states

102. Memorandum from Herb Kuhn, Director, Center for Medicare Management, to All Regional Administrators (May 7, 2004), available at http://www.cms.hhs.gov/WorkersCompAgencyServices/ Downloads/5704Memo.pdf.

103. Welch, supra note 46 , at 9.

104. John J. Campbell, New Federal Legislation Regarding Medicare Set-Asides is Introduced in the House of Representatives, The Medicare Set Aside Bulletin, May 9, 2006, http://www.jjcelderlaw .com/hr5309MSABulletin.htm.

105. Brief of the Ass'n of Trial Lawyers of Am. as Amicus Curiae in Support of Respondents, supra note 17, at 19-20. While the Ahlborn case deals with a state Medicaid lien, ATLA indicates that many of the arguments presented also apply to other government healthcare programs, such as Medicare. Id. at 2. 
generally. ${ }^{106}$ If the MSP statute is expanded to cover future medical expenses in personal injury cases, such an equitable apportionment could be a solution for determining the appropriate amount of a personal injury settlement to fund a MSA account. This proposal would eliminate the conflict of interest inherent in the current workers' compensation model, in which CMS has both the incentive to make the MSA amount as high as possible as well as the final authority to determine the set-aside amount, with no opportunity for the plaintiff to appeal CMS' decision. ${ }^{107}$

\section{Recently Proposed Federal Legislation to Change the Medicare \\ Secondary Payer Statute Regarding Workers' Compensation Settlements and Medicare Set Aside Arrangements}

In May 2006, House Bill 5309 was introduced which, if enacted, would make significant changes to how the MSP statute applies to workers' compensation settlements. ${ }^{108}$ The bill provides guidance in calculating the setaside amount and addresses many of the problems with the current worker's compensation model of MSA arrangements. For instance, the problem of lengthy wait times for MSA approval is addressed by granting automatic approval of any set-aside proposal unless a notice of determination of disapproval is received within sixty days of receipt by CMS. ${ }^{109}$ The bill also permits the costs of "establishing, administering, or securing approval for the Medicare set-aside" to be paid out of the amount set aside. ${ }^{110}$ The current problem of a lack of an appeals process for a CMS set aside determination is resolved by entitling a party to a reconsideration by CMS (within 30 days of requesting one), a hearing with an administrative judge (within 90 days of requesting one), and subsequent judicial review. ${ }^{111}$

The bill also includes an option to pay the MSA amount directly to CMS. ${ }^{112}$ However, rather than an arrangement in which CMS administers the MSA accounts, this option appears to be a direct, irrevocable assignment. Because under the proposed bill, MSA administration expenses may be paid out of the MSA account, no financial incentive to make an up-front transfer

106. Id. at 20-21.

107. See supra notes $85-88$ and accompanying text.

108. Medicare Secondary Payer and Workers' Compensation Settlement Agreements Act of 2006, H.R. 5309, 109th Cong. (2006).

109. H.R. $5309 \S 2(\mathrm{~b})$.

110. $I d$.

111. $I d$.

112. $I d$. 
directly to CMS would exist. ${ }^{113}$ Furthermore, such an upfront payment may also eliminate the opportunity for remaining MSA funds to be distributed to a selected beneficiary at the individual's death. ${ }^{114}$

One of the most significant changes proposed by the bill is a complete exemption from the MSP statute (as opposed to the current CMS review threshold) of any workers' compensation settlement with a present value of less than $\$ 250,000$, adjusted annually based on the national wage index, as well as any compromise settlement with a "present value that is not more than 20 percent of the present value of the total amount that could have been payable under the applicable workers' compensation law or similar plan if the claim involved had not been subject to a compromise[.]"115 The $\$ 250,000$ "present value" is generously calculated, as it could be based on the purchase price of an annuity (as opposed to the projected payout) and would not include, for instance, the amount needed to satisfy prior unpaid medical expenses, Medicaid liens, attorney fees for the claimant, etc. ${ }^{116}$ The bill also provides a "safe harbor" option for determining a qualified MSA amount, which would be the greater of " 10 percent of the present value of the agreement" or 15 percent of the payments provided by the agreement for total medical expenses. ${ }^{117}$ While it is sensible to exempt certain smaller settlements from the demands of the MSP statute, the proposed bill has also been criticized for making the exemptions too large and the safe harbor too easily manipulated, potentially shifting tremendous cost from workers' compensation carriers onto Medicare. ${ }^{118}$

\section{CONCLUSION}

With approximately forty-two million Americans relying on Medicare for their healthcare coverage, the financial stability of the program is of critical importance, and the MSP statute is an important means of achieving this goal. ${ }^{119}$ Medicare's financial well-being, however, must be carefully balanced

113. John J. Campbell, Serious Problems with the New Proposed Federal Legislation Aimed at WCMSAs; and a Proposed Remedy, The Medicare Set Aside Bulletin, June 5, 2006, http://www.jjcelderlaw.com/HR5309IIArtMSABull.htm.

114. Id.

115. H.R. $5309 \S 2(\mathrm{a})$

116. $I d$.

117. H.R. 5309 § 2(b).

118. Campbell, supra note 113; Campbell, supra note 104.

119. The Henry J.Kaiser Family Foundation, Medicare Chartbook 2 ( $3 \mathrm{~d}$ ed. 2005), available at http://www.kff.org/medicare/upload/Medicare-Chart-Book-3rd-Edition-Summer-2005-Section-1.pdf(last 
with other important factors, such as a plaintiff's interest in being fairly compensated for an injury and the necessity of efficient litigation processes.

There are a number of compelling reasons for not applying the MSP statute to future medical expenses in personal injury settlements. Most significantly, there seems to be no legal authority to do so, at least where there has been no specific settlement allocation for future medical expenses, and Medicare lacks the regulatory authority to reapportion a settlement in personal injury cases. ${ }^{120}$ As for extending the reach of the MSP statute to specifically cover future medical expenses in personal injury cases, the problems with the current workers' compensation model, the complex nature of tort damages, the uncertainty of future medical requirements, the potential burden to plaintiffs in administering an MSA account, and the resulting disincentives to settle speak strongly against such an expansion.

Should the legislature determine, however, that Medicare's financial benefit in expanding the MSP to apply to future medical expenses in personal injury cases outweighs the countervailing interests, such an expansion should only occur after the serious problems with the current workers' compensation model of MSAs have been resolved, perhaps through legislation incorporating a number of the provisions of House Bill 5309. This would not address all of the issues presented by an expansion of the MSP statute into future medical expenses in personal injury cases, but would help prevent the "gorilla at the negotiations table" from reaching unnatural proportions.

visited Nov. 2, 2006).

120. See supra notes $56-59$ and accompanying text. 